\title{
Influence of Human Resource Processes on the Performance of Selected Manufacturing SMEs in Nairobi City County, Kenya
}

\author{
Victor K. Kering, James M. Kilika and Jane W. Njuguna
}

\begin{abstract}
Manufacturing firms in Sub-Saharan Africa are not optimally managed which substantially lowers their productivity. The informal approach to human resource management is attributable to poor management practices with a consequent effect on performance. Due to these challenges, this study sought to examine the effect of human resource processes on the performance of manufacturing SMEs in Nairobi City County, Kenya. The study was explanatory and was based on 136 manufacturing SMEs which was drawn using proportionate stratified sampling. Data collection was achieved through the use of a self-administered questionnaire which was subjected to an inter-consistency test using the Cronbach's coefficient, $\alpha \geq$ 0.70 , which indicated that the research instrument was reliable. Descriptive and inferential statistics (at 0.05 significance levels) was used for the analysis of data. Diagnostic tests were conducted before regression analysis with the data was presented in tabular format. The results show that human resource processes cumulatively explain $23 \%$ of the variations in firm performance, therefore, the study concludes that the human resource processes have a positive influence on firm performance. The study recommends that manufacturing firms should seek to entrench an HR philosophy with commensurate improvements in the HR practises. The study limitations include a relatively small sample and geographical scope.
\end{abstract}

Index Terms - Human resource processes, Human resource practises and systems, Manufacturing firms, Small and Medium Enterprises (SMEs).

\section{INTRODUCTION}

The manufacturing firms in Sub-Saharan Africa (SSA) are less productive and lag behind other regions in terms of productivity and growth [14], [20] with inferior firm performance [67]. Across all SSA countries, there is evidence that the relationship between a country's income per capita and the share of manufacturing in GDP is weak [74] in that the manufacturing sector averagely accounts for eight per cent of GDP [21]. Within the East African Context, Kenya and Tanzania, have a GDP share of the manufacturing sector similar to the United States (12\%) and the UK (10\%). However, their manufacturing value addition (MVAs) are typically lower than those associated with emerging economies of between $30 \%$ to $40 \%$ [1].

The manufacturing sector is one of the economic pillars targeted by the Kenyan government for the creation of employment and wealth [75]. The challenge to the attainment of this endeavour is the underperformance as indicated by the

Published on December 30, 2020.

Victor K. Kering, Tutorial Fellow, Department of Business Administration, School of Business, Kenyatta University, Kenya.

(corresponding e-mail: kiriongi@gmail.com).

James M. Kilika, Senior Lecturer, Department of Business Administration, School of Business, Kenyatta University, Kenya.

(e-mail: jmkilika@ gmail.com). performance indices. The performance indices of the manufacturing sector in Kenya show that all the indicators; GDP contribution, MVA, employment, and growth have stagnated or declined in some years.

For instance, the contributions to GDP were $12 \%$ in 2008 before gradually easing to an average of $10 \%$ in subsequent years, while the manufacturing value-added component (MVA) was $10.80 \%$ in 2008 and gradually dropped to $8.90 \%$ in 2013 and further decreased to $1 \%$ in 2017 before gradually easing back to $6 \%$ in 2019 . The contribution of the sector to employment has averaged 13 per cent, and the growth rate is dismal and ranges between $1.30 \%$ in 2009 to $4.80 \%$ in 2013 to $4.20 \% 2018$ [34]-[53].

The indices highlight the predicament facing the policymakers. On average, the manufacturing sector has been growing at a slower rate than the economy showing that the share of manufacturing in the GDP has been reducing over time. Due to this contraction, Kenya can be said to be undergoing premature de-industrialization, a scenario, where the manufacturing and industry are still relatively underdeveloped [75]. Due to this scenario, the Government of Kenya has sought to increase the share of the manufacturing sector from the current $9.2 \%$ to $15 \%$ in the Medium-Term Expenditure Framework (MTEF 2018-2020) and 20\% as per the vision 2030 [26]. Despite government efforts to improve the returns of the sector, the sector has been underperforming.

There exists large cross- country variation in business practices which largely determine firm performance. To say the least, firm ownership plays a key role in determining the nature and kind of business practices of the business enterprise, and since most SMEs are owner-operated the business practises will be largely determined by the owner [60]. In comparison to large firms, SMEs have significant resource limitations, thereby restricting their option for improving their performance. Therefore, the management of human capital will confer them with commensurate capabilities to enable them to compete with large firms. Consequently, the effective management of human capital may ultimately determine organizational performance [68].

HRM is considered a large company phenomenon, but the SMEs can benefit more from structured HRM practices more than large companies because of their resource limitations [18]. Thus, the successful implementation of the properly aligned HRM practices would lead to improved performance

Jane W. Njuguna, Lecturer, Department of Business Administration, School of Business, Kenyatta University, Kenya.

(e-mail: wanjirajk2001@ gmail.com) 
outcomes [25]. Because of their resource limitations, the success of an SME largely depends on the quality of its human resource, but then, the SMEs pay less attention to HRM practices when compared to their larger counterparts [25].

There is a widespread use unsophisticated HRM practices among SMEs, a fact that is associated with unsatisfactory HR outcomes, but, the empirical evidence suggests that the adoption of sophisticated HRM practises leads to superior performance [5]. Therefore, by examining the differences in the structures used for the management of the human capital, one notices that glaring differences between the countries and the effect of HR. For instance, [68] observed that in developed economies, the formal and informal HRM practices are greatly influenced by the broader legal and regulatory framework, this contributes to the formalization of the HRM practices. This arrangement would largely impact on the organizational outcomes of the SMEs in these countries. In the developing economies, [73] noted that the firm's level HRM practices are largely informal and tend to have a profound effect on business performance.

Because of the contribution of the HRM to the organizational outcomes, [8] emphasized for the need of a process-based perspective of the HRM which stresses on two HRM aspects; good HR practices and its accompanying implementation. Guest [27] also highlighted the importance of the institutional perspective to the HRM processes which would ensure the adoption of a minimum set of HR practices in many organizations. Considering that HRM practices are a multidimensional construct with four main facets of recruitment and selection, human resource development, employee performance evaluation, and compensation management of employees, there is a need for a strong HRM climate and systems [25]. Whereas the specific HRM practices form the content of the HRM system which are critical practices for the achievement of organizational goals, the HRM system forms the process-based perspective of the HRM which deals with the overall structure of the organizational HRM activities that are geared toward the alignment of employee attitudes and behaviours [8].

Based on the need for a strong HRM setting and systems, the organizational HR systems should be structured to provide order, stability, and rationale to its members. Structuring of the processes also provides directions and control to the membership [7], [32], while diminishing the perceptions of uncertainty in the system. Structuring of HRM processes should help managers translate their vision and strategy into a working plan, thus enabling a strategic alignment via the reinforcing set of practices [7]. Thus, the use of structured HRM processes provides links for studying the organizational unit, department and individual level climates, inputs and outputs.

Structuring of HRM processes involves the creation of the managerial framework of explicit and clear HRM policies which are then translated into institutionalized and systematic modes and recurrent patterns of activity within the organization [7]. When structured, the human resources processes will be concerned with the development of HR strategies, policies, and practices that affect all aspects of HR and employee management [29]. These processes draw from the human capital theory that suggests that individuals possess the knowledge, experience, and skills which are of economic value to the organization, while the RBV theory posits that the organization's human capital is used to attainment and sustenance of competitive advantage when organized and streamlined by the HRM processes [30].

There are outstanding issues regarding the mechanism through which HRM is associated with different organizational outcomes. Some researchers have adopted the behavioural perspective which examines the role of HR practices in aligning employee behaviour, while others prefer the human capital and resource-based perspective which focuses on the contributions of the employee competences [24]. Due to these conceptual differences, the study posits that the structure of the HRM processes is associated related to the organizational performance and therefore seeks to examine the effect of human resource processes on the performance of selected manufacturing SMEs in Nairobi City County, Kenya.

\section{Problem Statement}

Studies have reported of the direct effects of complementary HRM practises on the firm's economic performance but a majority of the studies have hypothesized empirical links between a set of complementary HRM practices and economic performance [55]. These studies are organized around three important themes of HR practices [2] [22], HRM systems [57] and HRM configurations [77]. Other studies have progressively highlighted the integration of functions at the management level [22], [77] but none has emphasized on the effect of human resource processes.

The observable differences in management practices across firms and sectors tend to explain how the firm structure and manage their human capital [23]. This is one of the reasons why there is often an inadequate emphasis on human relations aspects in the SMEs when compared against multinational subsidiaries [60]. This problem is highlighted by the manufacturing sector in Kenya which faces several HRM challenges arising from the low management capacity, endemic and wanting productivity and difficulties in attracting and retaining skilled individuals [75]. Due to the aforementioned challenges, the paper sought to examine and measure the effect of human resources processes on the performance of manufacturing SMEs in Kenya.

\section{LITERATURE REVIEW}

\section{A. Theoretical Review}

The theoretical arguments to the human resource processes are provided by the resource-based, dynamic capability, institutional and cognition theories. The resource-based theory asserts that human capital is the prime assets to an organization and thus, investment in HR generate worthwhile returns. The human capital represents the human factor in the organization and includes the combined intelligence, skills and expertise that distinguishes organizations [4]. In this definition, the people and their collective skills, abilities and experience, coupled with their deployment within the organization constitute significant sources of competitive advantages. Thus, the management of organizational HR 
systems and its complementary structure should be congruent with the organizational strategy [4].

HRM is one of the most critical and important organizational processes as it develops the appropriate capabilities and creates competitive advantages [3], [13]. Its most important HRM practices relate to the attractions, selection, training, evaluating and rewarding employees [55]. The HRM practises form organizational capabilities which include among other things, the managerial capabilities to undertake strategic planning aspects, design appropriate organizational structures and coordinate the different functions and departments which reinforce the sets of role behaviours to create a firm's identity [56]. In this manner, an organization can derive competitive advantages from a welldeveloped HRM characterized by unique historical conditions, causal ambiguity, inimitable, and social complexity [11], [30] and are linked to the characteristics of employees, including their expectations and needs [56].

Organizations are reliant on the human element for their dynamic capabilities of learning, changing and innovating [4] and thus they can draw from the organizational managerial processes, procedures, systems and structures to strengthen the firm's human resource capabilities [72]. These important capabilities which include the dynamic managerial capability allow the firm's management to alter the firm's resource base in response to changes in the competitive environment [15], attainment of the sustainable competitive advantage and development of human resource advantages from the superior firm's HRM processes comprising of human capital and human process advantages [4]. In this manner, the firm-level differences in capabilities or sets of unique routines are fundamental to understanding the performance differences [15].

Organizations compete for several elements; resources, customers, political power, and institutional legitimacy and therefore seek social approval as well as economic performance [19], [61]. This creates an institutional environment where many of the organizational HRM practices are a reflection of the rules and structures in the larger institutional environment [62], [64]. Due to these institutional forces, members of a common organisational field such as the industry and stakeholders tend to develop isomorphism as a way of counter the environmental forces [62]. It is through, this isomorphism, that institutional forces influence the way the firms determine the compensation and rewards systems. For instance, government regulations influence the types and forms of corporate entities, equal employment practices, and minimum wage legislation.

The cognition theory asserts that cognition involves the development of mental models that an individual uses to make sense of their world and to make decisions [71]. An individuals' cognition arises as a result of experiences throughout life in various settings and through interactions with other people [12]. This allows humans to function intelligently, else, human perception and memory would be rapidly overloaded with insignificant details [70]. Thus, the rational agents are cognitively homogenous, sharing identical, complete knowledge relative to their industry and the choices it affords.

The firm's management is a rational being who derive their managerial cognitive styles from individual cognition and use the same cognitive skills to understand how business can manage their human capital [12]. it is because of managerial cognition that larger organizations tend to adopt more sophisticated HRM systems while smaller organizations are less likely to adopt the due process, procedures, employment involvement practices, sophisticated staff, and training and development procedures [30]. Furthermore, shared strategic cognition is important in predicting organizational performance [12].

\section{B. Empirical Review}

The empirical studies on the human resources processes have described how the firms structure its human capital within the internal context with an impact on performance. These studies have been organized around three important themes of HR practises, HRM systems and HRM configurations. The designs of these studies were focused on the determination of the influence of the HRM on the organizational and take two forms, the proximal HR outcomes or employee outcomes which helps align employee attitudes and behaviours, and the distal HR outcomes which relate to the organizational outcomes such as productivity and performance [76].

The earlier themes in studies were concerned with individual or standalone HRM practices, [55] and were built upon Pfeffer's [66] $16 \mathrm{HRM}$ practises which sought to establish the effect of the HR practises on organizational outcomes. This theme was illustrated by a study on the US manufacturing industry which observed a positive effect HR practises on performance [16]. Dolan et al. [22] examined the Spanish manufacturing sector and found that specific HR practises including recruitment and selection policy, flexible working arrangements and the use of performanceassessment system significantly resulted in higher financial performance. Further, the comparative analysis of manufacturing firms in Germany, Italy and Japan reported an indirect effect of the HR practices on the performance through the work environment [2]. Delmotte et al. [17] observed that HRM intensity practices positively influence labour productivity and on the operational performance outcomes. However, caution must be taken to note the fact that the use of the HR practices in studies is limited to the HR practices themselves without consideration of the human context of the HRM [27].

The studies on HR practises were followed by complementary HRM practices in the 1990s [55] and emphasized on the bundles of HR practices, often referred to as high -performance work systems (HPWS), highinvolvement work systems, and high-commitment work systems [24]. These complementary HRM practices are grouped into two approaches, system and interaction. Whereas the interaction approach looks at the effect of a few organizational practices, the systems approach examines the relative performance of the entire set of HR variables [55]. But then, the dominant theme in studies on HRM practice is the systems approach which in addition to measuring the effect of the bundles of HRM practices, also measures the indirect effects of complementary. These studies include those done by [65] who observed a direct effect of the HR practises on performance of UK firms. Based on the CFA, the study showed that empowerment HR practises such as job 
enrichment and skill enhancement correlated and predicted productivity and profitability. In the US manufacturing sector, [77] used regression analysis and confirmed that the enhancement HR system directly associated with multiple dimensions of operational performance.

The review above shows that the HR practices tend to focus on the individual components of the HRM systems and has a specified outcome, while, the HRM system approach argues that different sets of HR practices may impact the same outcomes differently [24]. Because an HRM system is a bundle of coherent mutually reinforcing [10], the use of systems of HRM practices which is commonly referred to as an HRM system is associated with higher HR outcomes such as greater employee commitment, higher productivity and, lower turnover [25]. Accordingly, different dimensions of HR systems have unique relationships with specific organizational outcomes [24] as observed by [55] who indicated that several studies have reported of the direct effects of complementary HRM practises on the firm's economic performance.

These studies on the HRM systems on performance have been done in different contexts. Dolan et al. [22] underscored the impact of the HR departmental characteristics and other organizational parameters in explaining variations in performance. The study indicated that HRM policies and practices play predicting the financial success of the firm in the medium - run. However, the HR practices as a composite system explain significant variations in the organizational performance, more than the HR Department or organizational characteristics. Similarly, [57] studied the Chinese manufacturing firms and affirmed that the high-performance HRM system significantly associated with performance. Thus, the HR system strengthens operational performance by improving productivity even when the industry environment, firm size and manufacturing strategy are controlled [77].

Therefore, the determination of the impact of the HRM systems should assume a broader and larger view which considers the structure of the HRM processes as opposed to HRM practices and systems [24]. This is what the scholars are advocating for studies seeking to establish the HRM-firm performance relationship. The structure HR processes take two; the system approach and the alignment approach. The systems approach considers the overall configuration or aggregation of HRM practices, while the alignment seeks to horizontally orient the various HRM practises [8]. This is because the HRM processes take an integrated approach and explain the relationship between the different organizational outcomes such as the proximal outcomes (HR outcomes) and distal outcomes (financial outcomes) [24].

The set of studies which take an integrated approach, where the HRM system forms a configurational setting of the HR practises as a unified whole to influence the organizational outcome. The effect of HR configuration not only relates to the HRM systems but its alignment to other business functions and the environment. This perspective has been highlighted by [77] which identified the influence of contingency approach to HR accounts on business performance of the US manufacturing sector while [16] indicated that universalistic perspective to HR has a larger effect on performance than other perspectives. This would indicate contrasting results, however, validates the alignment of the HRM systems within the organization.

The other line of studies has focused on the indirect effects of the HR processes on firm performance. These studies have either approached the HR practises and systems from the moderated or mediated effects and include; [16] who reported the mediating effects of the firm's strategy on the HR practises - performance linkages, [2] emphasized on the mediating effect of the organizational commitment on the HR practices - performance linkages, while, [77] tested for the moderating effect of the firm's manufacturing strategy on the HR-performance link. Shaukat et al. [68] reported the moderating effects of firm's HRM practices on the strategymaking process, HRM policies and outcomes. Katou and Budhwar [31] observed the moderating effect of the HRM outcome of skills and attitudes on the link between HRM systems and organizational performance in the Greek manufacturing sector.

The studies show that a firm's human capital management and practices can be studied at different levels [73]. First, at the individual HR practises where HR practises has a significant influence on proximal or/and distal organizational outcomes [2], [16], [17], [22], [55]. However, caution needs to be applied to these studies in that there is little empirical evidence that HR practices, individual or collectively are causally related to the overall firm performance or whether these effects are augmented by the use of other HR practises [9]. Second, the studies on the HRM systems have linked the HRM systems to the organizational performance [22], [25], [55], [57].

Third, the higher-level studies have focused on the integration of HRM practises into HR configuration have linked organizational performance to a firm's HR configuration [2], [77]. Based on this viewpoint, [8], [24] advocated for the broader view of the firm's HRM systems which considers the integration and structuring of the HRM processes with a focus on the horizontal alignment of the various HRM practises as opposed to HRM practices and systems [7]. It is from this basis that the paper considers the approach as the most appropriate for the measurement of the organizational outcomes. These studies have apprised the most significant aspect of the HRM which include HR, practices, HR systems and configuration, however, these practises, systems and configurations are not exhaustive and are not functionally integrated or linked. Further, these studies show the differences in the context and techniques and, this confers other researchers with an opportunity for carrying out studies based on the holistic and functional integrated processes of the firm's HR function.

\section{Methodology}

\section{A. Research Design}

The research used an explanatory design because the design is most appropriate in instances when one seeks to establish a causal relationship between the study variables. The design was suitable given that the phenomenon of interest is explicitly known and therefore, the researcher sought to establish the linkages. The use of the design was accompanied by a survey approach which allowed for the 
collection of sets of quantitative data from any given population.

\section{B. Sampling Procedure}

The study used a target population of 439 manufacturing firms registered with the Kenya Association of Manufacturers, Nairobi Chapter. These firms were clustered into 12 productive sectors of Food \& Beverages, Building, Construction \& Mining, Energy, Electrical \& Electronics, Metal \& Allied, Paper \& Board, Motor Vehicle \& accessories, Plastics \& Rubber, Leather \& Footwear, Chemical \& Allied, Pharmaceuticals \& Medical Equipment, Timber, Wood \& Furniture and Textile \& Apparel [33]. Because of the clustering by the association (KAM), the firms can be considered to have homogeneous characteristics, which allowed for the use of stratified random sampling technique

The sample size of 196 was arrived at through the use of the published tables [6]. Further, a finite correction factor was used when the target population is finite given and, the equation is given below:

$$
\mathrm{n}=\frac{\mathrm{n}_{0} \mathrm{~N}}{\mathrm{n}_{0}+(\mathrm{N}-1)}
$$

where $\mathrm{N}$ represents the population and $\mathrm{un}_{0}$, sample size without considering the finite population correction factor.

Then, the actual sample size

$$
\mathrm{n}=\frac{196 * 439}{196+(439-1)}=\frac{86044}{634}=136
$$

Thus, the study used 136 firms.

\section{RESEARCH INSTRUMENTS}

\section{A. Instrument Development}

The process of instrument development involved several phases. The first phase was the identification and the adoption of indicators from earlier studies on the HR processes, procedures and practices [22], recruitment, development, and rewarding [22], [65], productivity measurement [59], employee involvement [56], streamlining and integration of HR pool [2], [54]. The second phase involved the review of the instrument and its measurement by the faculty members, School of Business, Kenyatta University. After the review, the study used a monadic five-point Likert - type scale and the items required the respondents to rate their perceived human resource processes on a five-point Likert scale ranging from 1 - Not at all (N); 2 - Rarely (R); 3 - Occasionally (S); 4 - Frequently (O); and 5 - All the time (A)

To further assess the face validity, the questionnaire was pre-tested in a pilot study in Eldoret town whose manufacturing sector is distinctly separate from the study location. Lastly, the study cross-validated the instrument by measuring its construct validity. The values for the average variance extracted was 0.586 , while the composite reliability was 0.771 and, both met the threshold of 0.5 for convergent validity and 0.70 for construct validity. Lastly, the researcher ran a reliability index for the instrument and, the Cronbach alpha coefficient for the items and the coefficient had a value that was above 0.70 indicating that the instrument had the acceptable level of measurement and scale.

\section{DATA ANALYSIS}

The data collected were entered into STATA software, analysed using the descriptive statistics and, regression analysis while the output was presented in a tabular format. Because of the large data sets, the geometric mean was used to reduce the vast quantity of information while summarizing the individual responses to a single numerical index used for further analysis. Before the regression analysis, diagnostic tests were carried out. The study modelled the effect of human resource processes on firm performance:

$$
\mathrm{Y}=\beta_{0}+\beta_{1} \mathrm{X}_{1}+\varepsilon
$$

where $\mathrm{Y}$, was the dependent variable firm performance measured by sales growth over three years, while $X_{1}$ was the independent variable, the indicators for measuring human resource processes.

\section{RESULTS AND DISCUSSION}

\section{A. Descriptive Analysis}

The variable human resource processes were conceptualized as the specific HR practices that relate to human capital management structures, HR configurations, organizational training, development and rewards systems, employee involvement and the embeddedness of the HR and was operationalized by 30 items as indicated in Table 1 below.

TABLE 1: DESCRIPTIVE STATISTICS ON HuMAN ResouRCE PROCESSES

\begin{tabular}{cccc}
\hline Variable & \multicolumn{3}{c}{ Statistics } \\
\hline Variable Items & N & Mean & SD \\
\hline Human capital management structures & 44 & 3.818 & 0.523 \\
Human resource management & 44 & 4.150 & 0.797 \\
$\quad$ configurations & 44 & 3.784 & 0.756 \\
$\begin{array}{c}\text { Human Resource Development } \\
\text { Productivity measurement and } \\
\quad \text { compensation }\end{array}$ & 44 & 3.961 & 0.931 \\
$\begin{array}{c}\text { Employee involvement in organizational } \\
\text { matters }\end{array}$ & 44 & 3.945 & 0.756 \\
$\quad$ Human resource embeddedness & 44 & 3.858 & 0.893 \\
Human Resource processes & 44 & 3.935 & 0.782 \\
\hline
\end{tabular}

Source: Research Data (2019).

As shown in Table 1, most for the organizations studied were found to have established an independent functioning human resource department $($ Mean $=3.818, \mathrm{SD}=0.523)$ as opposed to having a loosely structured, and informally HR function. This indicated that these SMEs have a properly constituted and structured HR function to support organizational strategies and activities. Accordingly, the presence of a structure HR department is a precursor to a structured execution of HR function and activities. Most firms prefer the adoption and usage of the standardized conventions (Mean $=4.150, \mathrm{SD}=0.797)$. This indicates that these firms principally use the universalistic perspective more than any other configuration. The use of the universalistic approach to HRM by these firms finds is supported by [58] 
who indicated that this configuration is adopted because of several reasons that include its impact of complementarity of bundling HRM practises and the general acceptance of the universality of application regardless of the organizational and institutional contexts.

The firms surveyed use the internal development of staff (Mean $=3.784, \mathrm{SD}=0.756)$ as opposed to acquiring skills and experience outside the firm, with well-defined career ladder for the development of human capital. This would also mean that firms encourage teamwork and collaboration across the rank-and-file employees. Regarding productivity measurement and compensation, firms use extensive training coupled with the use of results-based measures (Mean = 3.961 , SD $=0.931$ ) for the measurement of productivity. These firms use of basic compensating forms which involve the use of salaries, wages and statutory contributions (NHIF and NSSF). The use of incentivised compensation scheme is an important HR practises as illustrated by several studies [16] [28] [66].

There are no employment guarantees among these firms, however, firms tend to regularly consult employees on matters pertaining to their welfare (Mean $=3.945, \mathrm{SD}=$ 0.756). Employee involvement is an important issue as it has been shown that these practices influence employee behaviour and attitudes with a consequent positive impact on employees' job performance and enthusiasm for work [57]. These firms tightly define their job specification because these firms considered the existence of an effective pool of human capital offers them a sustainable competitive advantage (Mean $=3.858, \mathrm{SD}=0.893$ ). The embeddedness of the HR function within the surveyed firms can be said to be taking shape as this is allowing the entrenchment of the HR processes.

\section{B. Diagnostic Tests}

The following diagnostic tests were carried out to test regression assumptions: normality, linearity, linear association, heteroscedasticity and collinearity. The target population was less than 2000 in number, thus the ShapiroWilk test for normality was used. The statistic, $W=0.9662$ ( $p$ $>0.05$ ) indicated that data was drawn from a normally distributed population. The linearity test was examined through the use of pictorial patterns of scatter and curvefitting plots and the indications from these plots showed that the study variables took the linear functional format, where $y$ $=\mathrm{a}+\mathrm{bx}$.

Heteroskedasticity was examined through the use of Breusch-Pagan-Godfrey test with the test statistics, $\chi^{2}=$ $1.69(\mathrm{p}>\quad 0.05)$ indicating that data exhibited homoscedasticity. The test for collinearity among the independent variables was carried out using the variance inflation factor $(\mathrm{VIF}) \leq 10$ and a tolerance figure, $1 / \mathrm{VIF} \geq$ 0.1 . The statistic, VIF $=1.00$, while $1 / \mathrm{VIF} \geq 0.1$, indicated that multicollinearity was not encountered. Lastly, test for linear association between variable was carried out using Pearson's Correlation coefficient and the statistic, $r=$ $0.4963(\mathrm{p}<0.05)$ indicated that human resources processes positively correlates with firm performance.

\section{Inferential Analysis}

Linear regression was carried to determine the effect of the human resource processes on firm performance are shown in Table 2 below.

TABLE 2: REGRESSION ANALYSIS RESULTS

\begin{tabular}{lcccc}
\hline Variable & $\mathrm{R}^{2}$ & $\mathrm{~F}$ & $\mathrm{Stn} \boldsymbol{\beta}$ & $\mathrm{t}$ \\
\hline Human Resource Processes & 0.2463 & $13.73 *$ & 0.4963 & $3.70 *$ \\
\hline *Significance at 0.05 & & & &
\end{tabular}

Source: Research Data (2019).

The results shown in Table 2 indicates that the regression model is statistically significant $(\mathrm{p}<0.05)$ in explaining the variations in firm performance. The model shows that human processes explain $24 \%$ in firm performance with an effect size of 0.4963 . Based on the results, the findings show that human resource processes have a statistically significant effect on firm performance.

\section{Discussion}

The findings showed shows that human resource processes utilized by the management have a positive effect on the performance of manufacturing SMEs in Nairobi City County, Kenya. This finding is explained by several empirical studies. The starting point is that the performance outcomes of HRM are captured in several ways; the HR-related outcomes, the organizational outcomes and the financial outcomes [63]. This is informed by the earlier empirical studies which have provided cross-sectional evidence on the linkages between complementary HRM practices and economic performance [55]. Paauwe [63] reported that HR practices are weakly related to overall firm performance in that the HR practises tend to influence the proximal firm outcomes such as employee perceptions [8] and employee productivity [69], and, in turn, the positive employee behavioural outcomes lead to higher levels of organizational performance.

Earlier research has revealed that employees are usually exposed to an HRM system as opposed to singular HR practices whose specific impact are necessarily equivalent [24]. These studies show that the HR system directly impacts employee outcomes such as employee skills and motivation and the structure and design of work. These factors then influence employee behaviour, which translates into improved operating performance [76]. For instance, [25] showed that HRM systems influence the proximal HR outcomes that are strongly linked to labour productivity. The use of HR systems is often associated with positive proximal organizational outcomes such as greater commitment, higher productivity, better service performance, and lastly, financial performance [24]. This was also reported by [31] who indicated that HRM systems indirectly influences organizational performance of the Greek manufacturing sector.

Studies on HRM tend to show that HRM leads to performance [18], this is shown by the fact that the adoption of more HR practices was associated with higher performance [27]. Thus, the HRM systems as an additive set of individual HR practices whose impact would cumulatively build upon each other [24]. Several empirical studies and observation from several authors including [22] who observed the effect of the HR departmental characteristics on performance, [57] highlighted the influence of high- 
performance practises on performance. or employee performance [52]. Other studies have emphasized the effect of HR systems on performance [22], [31]. Further, [76] affirmed the effect of configurational HR systems on firm performance.

\section{CONCLUSION AND RECOMMENDATION}

\section{A. Conclusion}

Drawing from the findings, the study concludes that the unique human resource processes explain the variation in the business performance of manufacturing firms in Kenya. For instance, the use of universalistic HRM configurations across the board and the lack of permeating HRM philosophy may hinder the attainment of the firm's HR objectives with a consequent effect on performance.

\section{B. Recommendation}

These firms should adopt modern HR procedures and practises that would improve the configurations of the HR function

\section{Contributions, Limitations, and Suggestions for Future Research}

Based on the findings, conclusion and discussion the study contributes to the existing knowledge in strategic management. First, most empirical studies adopted a solitary approach of either individual dimension or unidimensional aspects of HR practises [22], [65] and high-performance HR systems [57] to explain the performance of the manufacturing sector in a developed country context. This indicates that there is a paucity of information on the human resource processes on the performance of manufacturing firms in subSaharan Africa.

Secondly, the current study contributes to the findings of the previous studies by inclusion of the process-centric perspective where the HRM processes are holistically advanced as a unit not as separate practices by using the case of Kenya and thus making it possible to make generalizations. These findings contribute towards understanding and the measurement of the impacts of human resource processes (HR practises, Human capital development structures, HRM systems, HR configurations and HR embeddedness) in a developing country context in Sub - Saharan Africa.

The study focused on measuring the effect of human resource processes on the performance of manufacturing SMEs in Nairobi City County, Kenya and, therefore other studies may seek to measure the HR configurations and processes of other industrial sectors in Kenya.

\section{REFERENCES}

[1] African Development Bank Group (2013). The State of Kenya's Private Sector. African Development Bank Group, Tunis.

[2] Ahmad, S. \& Schroeder, R. G. (2003). The impact of human resource management practices on operational performance: recognizing country and industry differences Journal of Operations Management. Elsevier. 21; 19-43.

[3] Ahmeti, F. (2015). Human resource management and practices in SMEs in developing countries: Practices in Kosovo. European Scientific Journal (ESJ), 11(7).

[4] Armstrong, M. (2006). A handbook of human resource management practice. Kogan Page Publishers.
[5] Bacon, N., \& Hoque, K. (2005). HRM in the SME sector: valuable employees and coercive networks. The International Journal of Human Resource Management, 16(11), 1976-1999.

[6] Barlett, J. E., Kotrlik, J. W., \& Higgins, C. C. (2001). Organizationa research: Determining appropriate sample size in survey research. Information Technology, Learning, and Performance Journal, 19(1), 43.

[7] Binyamin, G., \& Carmeli, A. (2010). Does structuring of human resource management processes enhance employee creativity? The mediating role of psychological availability. Human Resource Management, 49(6), 999-1024.

[8] Birdi, K., Clegg, C., Patterson, M., Robinson, A., Stride, C. B., Wall, T. D., \& Wood, S. J. (2008). The impact of human resource and operational management practices on company productivity: A longitudinal study. Personnel psychology, 61(3), 467-501.

[9] Boselie, P., Dietz, G., \& Boon, C. (2005). Commonalities and contradictions in HRM and performance research. Human resource management journal, 15(3), 67-94.

[10] Bowen, D. E., \& Ostroff, C. (2004). Understanding HRM-firm performance linkages: The role of the "strength" of the HRM system. Academy of management review, 29(2), 203-221.

[11] Boxall, P. (1996). The strategic HRM debate and the resource-based view of the firm. Human Resource Management Journal, 6(3), 59-75.

[12] Budhwar, P. S., \& Sparrow, P. R. (2002). Strategic HRM through the cultural looking glass: mapping the cognition of British and Indian managers. Organization Studies, 23(4), 599-638.

[13] Cania, L. (2014). The impact of strategic human resource management on organizational performance. Economia. Seria Management, 17(2), 373-383.

[14] Clarke, G. R. (2012). Manufacturing firms in Africa. Performance of Manufacturing Firms in Africa, 47.

[15] Chatterji, A., \& Patro, A. (2014). Dynamic capabilities and managing human capital. Academy of Management Perspectives, 28(4), 395408.

[16] Delery, J. E., \& Doty, D.H. (1996). Modes of Theorizing in Strategic Human Resource Management: Tests of Universalistic, Contingency, and Configurational Performance Predictions. The Academy of Management Journal, 39(4) 802-835.

[17] Delmotte, J., Maes, J., Faems, D., Forrier, A., \& Sels, L. (2006). Linking HRM and Small Business Performance: An Examination of the Impact of HRM Intensity on the Productivity and Financial Performance of Small Businesses. Small Business Economics, 26(1), 83-101.

[18] De Winne, S., \& Sels, L. (2010). Interrelationships between human capital, HRM and innovation in Belgian start-ups aiming at an innovation strategy. The International Journal of Human Resource Management, 21(11), 1863-1883.

[19] DiMaggio, P. J. \& Powell, W. W. (1983). The Iron Cage Revisited: Institutional Isomorphism and Collective Rationality in Organizational Fields. American Sociological Review, American Sociological Association, 48(2), 147-160.

[20] Dinh, H. T., \& Clarke, G. R. (Eds.). (2012). Performance of manufacturing firms in Africa: An empirical analysis. The World Bank.

[21] Dinh, H. T., Palmade, V., Chandra, V., \& Cossar, F. (2012). Light manufacturing in Africa: Targeted policies to enhance private investment and create jobs. The World Bank.

[22] Dolan, S. L., Mach, M. \& Olivera, V. S. (2005). HR contribution to a firm's success examined from a configurational perspective: An exploratory study based on the Spanish CRANET data. Management Revue, Rainer HamppVerlag, 16(2), 272-290.

[23] Fafchamps, M., \& Quinn, S. (2016). Networks and manufacturing firms in Africa: Results from a randomized field experiment. The World Bank Economic Review, 32(3), 656-675.

[24] Jiang, K., Lepak, D. P., Hu, J., \& Baer, J. C. (2012). How does human resource management influence organizational outcomes? A metaanalytic investigation of mediating mechanisms. Academy of management Journal, 55(6), 1264-1294.

[25] Gamage, A. S. (2014). Recruitment and selection practices in manufacturing SMEs in Japan: An analysis of the link with business performance. Ruhuna Journal of Management and Finance, 1(1), 3752.

[26] Government of Kenya (2018). Accessed from http://www.industrialization.go.ke/images/downloads/vision-2030manufacturing-sector.pdf.

[27] Guest, D. E. (2011). Human resource management and performance: still searching for some answers. Human resource management journal, 21(1), 3-13.

[28] Huselid, M. A. (1995). The Impact of Human Resource Management Practices on Turnover, Productivity, and Corporate Financial 
Performance. The Academy of Management Journal, Academy of Management, 38(3), 635-672.

[29] Huselid, M. A, Jackson, S. E., \& Schuler, R. S. (1997). Technical and Strategic Human Resource Management Effectiveness as Determinants of Firm Performance. The Academy of Management Journal, 40(1), 171-188.

[30] Jackson, S. E., \& Schuler, R. S. (1995). Understanding human resource management in the context of organizations and their environments. Annual review of psychology, 46(1), 237-264.

[31] Katou, A. A., \& Budhwar, P. S. (2006). Human resource management systems and organizational performance: a test of a mediating model in the Greek manufacturing context. The international journal of human resource management, 17(7), 1223-1253.

[32] Kollenscher, E., Ronen, B., \& Farjoun, M. (2009). Architectural leadership: Building a value enhancing infrastructure. Human Systems Management, 28(1-2), 35-45.

[33] KAM (2015). Kenya Association of Manufacturers, www.kam. co.ke

[34] KNBS (2020). Economic Survey 2020, Kenya National Bureau of Statistics, https://www.knbs.or.ke/.

[35] KNBS (2019). Economic Survey 2019, Kenya National Bureau of Statistics, https://www.knbs.or.ke/.

[36] KNBS (2018). Economic Survey 2018, Kenya National Bureau of Statistics, https://www.knbs.or.ke/.

[37] KNBS (2017). Economic Survey 2017, Kenya National Bureau of Statistics, https://www.knbs.or.ke/.

[38] KNBS (2016). Economic Survey 2016, Kenya National Bureau of Statistics, https://www.knbs.or.ke/.

[39] KNBS (2015). Economic Survey 2015, Kenya National Bureau of Statistics, https://www.knbs.or.ke/.

[40] KNBS (2014). Economic Survey 2014, Kenya National Bureau of Statistics, https://www.knbs.or.ke/.

[41] KNBS (2013). Economic Survey 2013, Kenya National Bureau of Statistics, https://www.knbs.or.ke/.

[42] KNBS (2012). Economic Survey 2012, Kenya National Bureau of Statistics, https://www.knbs.or.ke/.

[43] KNBS (2011). Economic Survey 2011, Kenya National Bureau of Statistics, https://www.knbs.or.ke/

[44] KNBS (2010). Economic Survey 2010, Kenya National Bureau of Statistics, https://www.knbs.or.ke/.

[45] KNBS (2009). Economic Survey 2009, Kenya National Bureau of Statistics, https://www.knbs.or.ke/.

[46] KNBS (2008). Economic Survey 2008, Kenya National Bureau of Statistics, https://www.knbs.or.ke/.

[47] KIPPRA (2018). Kenya Economic Report 2018; Boosting Investments for Delivery of the Kenya Vision 2030. Kenya Institute for Public Policy Research and Analysis, Nairobi.

[48] KIPPRA (2017). Kenya Economic Report 2017; Sustaining Kenya's Economic Development by Deepening and Expanding Economic Integration in the Region. Kenya Institute for Public Policy Research and Analysis, Nairobi.

[49] KIPPRA (2016). Kenya Economic Report 2016; Fiscal Decentralization in Support of Devolution. Kenya Institute for Public Policy Research and Analysis, Nairobi.

[50] KIPPRA (2015). Kenya Economic Report 2015; Empowering Youth through Decent and Productive Employment. Kenya Institute for Public Policy Research and Analysis, Nairobi

[51] KIPPRA (2014). Kenya Economic Report 2014; Navigating Global Challenges While Exploiting Opportunities for Sustainable Growth. Kenya Institute for Public Policy Research and Analysis, Nairobi.

52] KIPPRA (2013). Kenya Economic Report 2013; Creating an Enabling Environment for Stimulating Investment for Competitive and Sustainable Counties. Kenya Institute for Public Policy Research and Analysis, Nairobi.

[53] KIPPRA (2012). Kenya Economic Report 2012; Imperatives for Reducing the Cost of Living in Kenya. Kenya Institute for Public Policy Research and Analysis, Nairobi.

[54] Kuvaas, B., \& Dysvik, A. (2010). Exploring alternative relationships between perceived investment in employee development, perceived supervisor support and employee outcomes. Human Resource Management Journal, 20(2), 138-156.

[55] Laursen, K., \& Foss, N. J. (2003). New human resource management practices, complementarities and the impact on innovation performance. Cambridge Journal of economics, 27(2), 243-263.

[56] Lopez-Cabrales, A., Valle, R., \& Herrero, I. (2006). The contribution of core employees to organizational capabilities and efficiency. Human Resource Management: Published in Cooperation with the School of Business Administration, The University of Michigan and in alliance with the Society of Human Resources Management, 45(1), 81-109.
[57] Lu, K., Zhu, J. \& Bao, H. (2015). High-performance human resource management \& firm performance, Industrial Management \& Data Systems, 115(2), $353-382$.

[58] Mak, S. K., \& Akhtar, S. (2003). Human resource management practices, strategic orientations, and company performance: a correlation study of publicly listed companies. Journal of American Academy of Business, Cambridge, 2(2), 510-510.

[59] Marimuthu, M., Arokiasamy, L., \& Ismail, M. (2009). Human capital development and its impact on firm performance: Evidence from developmental economics. The Journal of International Social Research (8), $265-272$.

[60] McKenzie, D., \& Woodruff, C. (2015). Business practices in small firms in developing countries. The World Bank.

[61] Meyer, J. W., \& Rowan, B. (1977). Institutionalized Organizations: Formal Structure as Myth \& Ceremony. American Journal of Sociology, The University of Chicago Press, 83(2), 340-363.

[62] Najeeb, A. (2014). Institutional theory and human resource management. Faculty of Business - Papers (Archive). 406

[63] Paauwe, J. (2009). HRM and performance: Achievements, methodological issues and prospects. Journal of Management studies, 46(1), 129-142.

[64] Paauwe, J., \& Boselie, P. (2003). Challenging 'strategic HRM' and the relevance of the institutional setting. Human Resource Management Journal, 13(3), 56-70.

[65] Patterson, M. G., West, M. A., \& Wall, T. D. (2004). Integrated Manufacturing, Empowerment, \& Company Performance. Journal of Organizational Behaviour, Wiley, 25(5), 641-665.

[66] Pfeffer, J. (1994). Competitive advantage through people. California management review, 36(2), 9.

[67] Sandrey, R., \& Edinger, H. (2011). China's manufacturing and industrialization in Africa. African Development Bank Group.

[68] Shaukat, H., Ashraf, N., \& Ghafoor, S. (2015). Impact of human resource management practices on employee's performance. Middle East Journal of Scientific Research, 23(2), 329-338.

[69] Snape, E., \& Redman, T. (2010). HRM practices, organizational citizenship behaviour, and performance: A multi-level analysis. Journal of management studies, 47(7), 1219-1247.

[70] Stubbart, C. I. (1989). Managerial cognition: A missing link in strategic management research. Journal of Management Studies, 26(4), 325-347.

[71] Swan, J. A. (1995). Exploring knowledge and cognitions in decisions about technological innovation: mapping managerial cognitions. Human relations, 48(11), 1241-1270.

[72] Teece, D. J. (2007). Explicating dynamic capabilities: the nature and micro-foundations of (sustainable) enterprise performance. Strategic management journal, 28(13), 1319-1350.

[73] Uden, A.V., Knoben, J., \& Vermeulen, P. (2017). Human capital and innovation in Sub-Saharan countries: a firm-level study. Innovationthe European Journal of Social Science Research, 19, 103-124.

[74] Weiss, J. A., \& Jalilian, H. (2016). Manufacturing as an engine of growth. In: Weiss $\mathrm{J}$ and Tribe $\mathrm{M}$ (Eds.) Routledge Handbook of Industry and Development. London: Routledge. 26-37.

[75] Were, A. (2016). Manufacturing in Kenya: Features, challenges and opportunities. International Journal of Science, Management and Engineering, 4(6), 15-26.

[76] Wright, P. M., Gardner, T. M., Moynihan, L. M., \& Allen, M. R. (2005). The relationship between HR practices and firm performance: Examining causal order. Personnel psychology, 58(2), 409-446.

[77] Youndt, M.A., Snell, S. A., Dean, J. W., \& Lepak, D. P. (1996) Human Resource Management, Manufacturing Strategy, and Firm Performance. The Academy of Management Journal, Academy of Management 39(4), 836-866.

Victor Kiptum Kering is a tutorial fellow at the Kenyatta University, Kenya undertaking his $\mathrm{PhD}$ studies in business with a bias in Strategic management. The author graduated with Bachelor of Science(chemistry) in 2000 from the University of Nairobi, Nairobi, Kenya, A Master of Business Administration (strategic management option) from the Catholic University of Eastern Africa in 2010 and Diploma in Information Systems from the IMIS Institute UK, 2007.

He has 12 years' experience in business management as a sales controller in Nairobi Kenya and ten years' experience as an assistant lecturer in business studies at different universities in Kenya including Catholic University of Eastern Africa, Mount Kenya University and University of Eldoret. $\mathrm{He}$ is interested in business and management consultancy and research. 